\title{
Occurrence of possible drug related interactions in medical patients in out-patient departments of Pakistan
}

\author{
Hammad A. Butt ${ }^{1 *}$, Ammara Khan², Naveed Suleman ${ }^{3}$
}

\author{
${ }^{1}$ Department of Pharmacology, CMH Kharian Medical College, Kharian, Pakistan \\ ${ }^{2}$ Department of Pharmacology, Nawaz Sharif Medical College, University of Gujrat, Hafiz Hayat Campus, Gujrat, \\ Pakistan \\ ${ }^{3}$ Department of Pharmacology, University of Health Sciences, Lahore, Pakistan
}

Received: 27 July 2020

Accepted: 01 September 2020

\section{*Correspondence:}

Dr. Hammad A. Butt,

Email: hammad034@gmail.com

Copyright: $\odot$ the author(s), publisher and licensee Medip Academy. This is an open-access article distributed under the terms of the Creative Commons Attribution Non-Commercial License, which permits unrestricted non-commercial use, distribution, and reproduction in any medium, provided the original work is properly cited.

\section{ABSTRACT}

Background: Data regarding occurrence of drug-drug interactions in Pakistan is rare. In the current study, we have tried to find out the clinical adversity and frequency witnessed in prescriptions of a medical outpatient department.

Methods: Patient prescriptions were analyzed for potential drug-drug interactions. A sample of 364 patients, visited outpatient department who were being prescribed at least two drugs simultaneously using a drug interaction program website.

Results: The 364 patients ( $72.8 \%$ male, mean age $57.9 \pm 15.2$ years) were prescribed a median of six drugs (range 213 ) at OPD visit. Three hundred forty nine patients $(95.8 \%)$ had at least one potentially interacting drug combination. 2636 potential interactions were seen in the visiting patients. Out of these $124(4.7 \%)$ were of major severity, 1730 $(65.6 \%)$ moderate and $515(19.5 \%)$. Out of 124 patients with a potential DDI with major severity, no patient was rehospitalized within 2 months after discharge due to a probable drug-related problem associated with the potential DDI.

Conclusions: A large percentage of patients were detected having one or more potential drug-drug interactions, using drug interaction detection program. However, the percentage of patients having clinically adverse consequences due to drug-drug interactions appears to be very low.

Keywords: Adverse drug interaction, Drug-related problems, Drug-drug interaction, Pharmacoepidemiology

\section{INTRODUCTION}

Drug-drug interactions (DDIs), being one of the most preventable drug related hazards having serious life threatening adverse consequences or at least results in therapeutic failure. ${ }^{1}$ The accompanying ADRs may cause severe morbidity or even mortality. ADRs result in 5\% admissions in healthcare settings, of which 0.25 to $25 \%$ are due to DDIs. ${ }^{3-6}$ Detection and proper prevention of DDIs result in avoiding the connected undesirable situations. ${ }^{7}$
DDIs are very widespread in hospital admitted patients. ${ }^{7-9}$ According to various studies conducted in certain wards of a healthcare setting, showed the data regarding reasons for hospitalization, class of drugs and patient populations. . $^{1,210-14}$ Studies regarding the DDIs occurrence in OPDs of Pakistan's hospitals are very inadequate and rare. A few studies reported in developed countries showed $28-83 \%$ prevalence of DDIs in OPDs., ${ }^{4,13,15-18}$ These examination are restricted by the nature of work settings, plan, DDIs screening tool, and drug prescribing pattern. 
Considerable number of causes account for the DDIs in outpatients. Healthcare providers in undeveloped and developed countries, including Pakistan, face various challenges i.e., overburdened patients in hospitals, with multiple diseased states, accompanied by unauthentic previous medication histories. ${ }^{19,20}$ In addition, there are no such methods available/adopted to determine the patients' drug adherences, therapeutic outcome levels and ADR reporting and highlighting systems. ${ }^{19,20}$ Overall, due to these miserable circumstances, it is inevitable to perform studies on DDIs occur in OPDs inside Pakistan.

The main of the study was to determine the prevalence of possible DDIs that are preventable by proper analyzing the prescriptions of the patients that visit OPDs. Also to evaluate the degree and intensity of the DDIs and to discover the widespread clinically significant interactions.

\section{METHODS}

\section{Patient and data collection}

All 364 patients visited the medical OPD of $\mathrm{CMH}$ hospital Kharian, Punjab, Pakistan at 22 June 2019, were enrolled in this study. This hospital is a 500 beds teaching institution that provides both primary and tertiary care facilities to the surrounding population of inhabitants.

Exclusion criteria was to not include patients who were being prescribed less than two drugs. Information on prescriptions was retrieved from the hospital prescription. Demographic information like age, sex, weight etc. Along with their principal diagnoses (according to ICD11 classification) were collected. Also the medication taken at hospital admission was retrieved from the clinical records. Anatomical therapeutic chemical (ATC) classification for drugs were being employed.

\section{Analysis of potential DDIs}

Possible DDIs were analyzed by using drug-reax, which is a computerized drug information and interaction system. This program unveils information about adverse drug reactions resulting from a DDI, the onset as well as the severity (major, moderate, minor) of a potential DDI. It provides information on potential clinical consequences (ADRs). It also reveals the underlying mechanism of the DDI and how well DDI is documented in the literature.

Patients experienced a potential DDI with major severity at discharge were screened whether they were rehospitalised within two months after visit and whether rehospitalisation was associated with possible DDIs.

\section{Data analysis}

The results of this study are expressed in proportions, mean \pm SD or in terms of medians within their corresponding ranges. A two tailed hypothesis testing was conducted and represented by p value less than 0.05 taken as statistically significant. SPSS for windows version 20.0 was used to analyze the data.

\section{RESULTS}

The studied population comprises of 364 patients, amongst them 265 were males and 99 were females. The mean age \pm SD was $57.9 \pm 15.2$ years. Also $38.4 \%$ of the total sample that equals to 140 patients consisted of age 65 years or above (Table 1$)$.

Table 1: Characteristics of the study population of 364 medical patients.

\begin{tabular}{|ll|}
\hline $\begin{array}{l}\text { Patients' demographics and disease } \\
\text { states }\end{array}$ & $\begin{array}{l}\text { Study } \\
\text { population } \\
(\mathbf{n = 3 6 4 )}\end{array}$ \\
\hline Mean age (years) & $57.9(15.2)$ \\
\hline$<65$ & $61.6 \%$ \\
\hline$\geq 65$ & $38.4 \%$ \\
\hline Sex (male) & $72.8 \%$ \\
\hline $\begin{array}{l}\text { Number of drugs prescribed } \\
\text { median (range) }\end{array}$ & $6(2-13)$ \\
\hline Main diagnoses according to ICD-11 & $25.8 \%$ \\
\hline Respiratory diseases & $25.0 \%$ \\
\hline Cardiovascular diseases & $17.6 \%$ \\
\hline Mental and behavioral disorders & $13.7 \%$ \\
\hline $\begin{array}{l}\text { Endocrine, nutritional and metabolic } \\
\text { diseases }\end{array}$ & $6.3 \%$ \\
\hline $\begin{array}{l}\text { Musculoskeletal and } \\
\text { connective tissue diseases }\end{array}$ & $11.6 \%$ \\
\hline \begin{tabular}{l} 
Others \\
\hline
\end{tabular}
\end{tabular}

Table 2: Ten drug classes most often prescribed to 364 medical patients at hospital.

\begin{tabular}{|ll|}
\hline Therapeutic class & $\begin{array}{l}\text { Number of patients } \\
\text { with a prescription } \\
\text { for this drug class } \\
(\%)\end{array}$ \\
\hline $\begin{array}{l}\text { Drugs for acid related } \\
\text { disorders }\end{array}$ & $222(60.9)$ \\
\hline $\begin{array}{l}\text { Drugs for obstructive airway } \\
\text { diseases }\end{array}$ & $121(33.2)$ \\
\hline $\begin{array}{l}\text { Agents acting on the renin- } \\
\text { angiotensin system }\end{array}$ & $100(27.2)$ \\
\hline Antithrombotic agents & $90(24.7)$ \\
\hline $\begin{array}{l}\text { Lipid modifying agents, } \\
\text { psychoanaleptics }\end{array}$ & $81(22.2)$ \\
\hline Vitamins & $80(21.9)$ \\
\hline Drugs used in diabetes & $78(21.4)$ \\
\hline Psycholeptics & $72(19.7)$ \\
\hline $\begin{array}{l}\text { Diuretics, } \\
\text { antiepileptics }\end{array}$ & $70(19.2)$ \\
\hline
\end{tabular}

A total of 2211 drugs were prescribed to 364 patients that lead to a median of 6 drugs per patient having range of 2 
to 13. As the drugs prescribed contained combination preparations, the cumulative total number of pharmacologically active ingredients was 3016 that corresponds to the total 2636 possible interacting drug combinations.

A median of 7 versus 5 drugs; $(\mathrm{p}<0.01)$ was found significantly higher in elderly $(\geq 65$ years $)$ patients as compared in younger or lesser than 65 years of age.

Amongst all drugs prescribed, 28\% were for alimentary tract and metabolic dysfunctions, $19 \%$ prescribed for respiratory problems, $18 \%$ were for the treatment of cardiovascular diseases, $15 \%$ pertained to nervous system, 7\% were prescribed for blood and blood forming organs, while the rest of $13 \%$ drugs were prescribed for the treatment of other organ systems. Ten therapeutic drug classes most often prescribed at discharge are listed in (Table 2).

\section{Potential DDIs}

Out of the total 364 patients, 349 patients proved to have possible drug-drug combinations. The median number i.e.
5.5 is the DDI in patients having possible interactions in range of 1 to 39 . Ten potentially interacting drug combinations leads to more than $20 \%$ of the 2636 potential DDIs (Table 3). $124(4.7 \%)$ DDIs were considered potentially major, $1730(65.6 \%)$ were having moderate while $515(19.5 \%)$ were of minor severity.

The documentation of major potential DDIs was good in $71.1 \%$, excellent, fair, and poor in $28.2 \%$, respectively. The computer-program-suggested onset of the potential major DDI was classified as delayed in 53\% and as rapid in $47 \%$. All DDIs associated with potentially severe clinical consequences are listed in (Table 4). These DDIs with potentially major severity were found in 103 patients corresponding to a proportion of $28.2 \%$ of all patients.

\section{Clinical relevance}

Out of 124 potential DDIs assessed as having potentially major severity, a majority $(29.8 \%)$ was due to a combination of an ACE inhibitor with potassium-sparing diuretics (spironolactone, amiloride, triamterene).

Table 3: Most common 10 drug combinations that were responsible for most of the potentially interacting drug combinations.

\begin{tabular}{|lllc|}
\hline Potential DDIs & Potential adverse effect & Severity & N (\%) \\
\hline Theophylline+Albuterol & $\begin{array}{l}\text { Hypokalemia, cardiovascular toxicity (palpitation, } \\
\text { tachycardia, and blood pressure elevation) }\end{array}$ & Moderate & $62(2.3)$ \\
\hline Theophylline+Salmeterol & $\begin{array}{l}\text { Hypokalemia, cardiovascular toxicity (palpitation, } \\
\text { tachycardia, and blood pressure elevation) }\end{array}$ & Moderate & $60(2.2)$ \\
\hline Theophylline+Omeprazole & $\begin{array}{l}\text { Increased theophylline concentration and toxicity } \\
\text { (nausea, vomiting, diarrhea, headache, restlessness, } \\
\text { insomnia, irregular heartbeat) }\end{array}$ & Moderate & $57(2.1)$ \\
\hline Aspirin+Omeprazole & Decreased concentration and efficacy of aspirin & Minor & $53(2.0)$ \\
\hline Aspirin+Losartan & $\begin{array}{l}\text { Decreased anti hypertensive effect, deterioration of } \\
\text { renal function }\end{array}$ & Moderate & $47(1.7)$ \\
\hline Furosemide+Aspirin & Loss of natriuretic and diuretic response of furosemide & Minor & $45(1.7)$ \\
\hline Omeprazole+Atorvastatin & Increased concentration of atorvastatin & Moderate & $45(1.7)$ \\
\hline Aspirin+Nitroglycerin & Increased anti hypertensive effect of nitroglycerin & Minor & $44(1.6)$ \\
\hline Albuterol+Salmeterol & Increased risk of cardiovascular side effects & Moderate & $38(1.4)$ \\
\hline Albuterol+Fluticasone & Hypokalemia & Minor & $38(1.4)$ \\
\hline
\end{tabular}

\section{DISCUSSION}

This study reveals the clinical adversity due to possible and prudent drug-drug interactions and the frequency of the drugs prescribed in out-patient department. The percentage of aged people (having age 65 or above) in our study is 38.4 considering a total of 364 patients. In contrast to a recent study that revealed $29.4 \%$ aged people (age 65 or above). ${ }^{22}$ The possible reason behind may be lesser health awareness, poor economic and balanced diet availability to the senior citizens in our country.
The predominance of DDIs in our findings show (95.8\%) that seems quite higher in comparison with the related previous studies conducted in other nations i.e. (27.9 to $83.4 \%) .^{4,13,15-18}$ The possible reason behind may be overburdened healthcare personnel due to patient overload in hospitals, severe lacking of patient's follow up monitoring system. Also deficiency in patient's DDIs detection facilities. Furthermore, there is not proper inductance as well as pharmacist utilization in healthcare settings. The government's lack of interest is another big issue that can aggravate the situation. Our study reveals minor to moderate intensity of main types of interactions. 
Table 4: List of 124 interacting drug combinations with potential major severity in the discharge prescriptions of 364 patients.

\begin{tabular}{|c|c|c|c|c|}
\hline Potential DDIs & Potential adverse effect & $\begin{array}{l}\text { Docum- } \\
\text { entation }\end{array}$ & Onset & $\mathbf{N}(\%)$ \\
\hline $\begin{array}{l}\text { Potassium-sparing } \\
\text { diuretics+ACE inhibitor }\end{array}$ & Hyperkalaemia & Good & Delayed & $37(29.8)$ \\
\hline SSRIs+TCAs & Serotonin syndrome, TCA toxicity & Good & Rapid & $25(20.1)$ \\
\hline Omeprazole +Clopidogrel & Reduced cardioprotection & Good & Delayed & $15(12)$ \\
\hline Methotrexate+Omeprazole & Increased methotrexate concentration & Fair & Delayed & $3(2.4)$ \\
\hline Ibuprofen+Aspirin & Loss of cardioprotective and anti platelet effect & Good & Delayed & $3(2.4)$ \\
\hline Ciprofloxacin+Theophylline & $\begin{array}{l}\text { Increased theophylline concentration and toxicity } \\
\text { (cardiac arrest, seizure, status epilepticus, } \\
\text { respiratory failure) }\end{array}$ & Good & Delayed & $2(1.6)$ \\
\hline Orphenadrine+Topiramate & Oligohidrosis, hyperthermia & Poor & Delayed & $2(1.6)$ \\
\hline Prednisone+Levofloxacin & Tendinitis, tendon rupture & Good & Delayed & $2(1.6)$ \\
\hline Tizanidine+Escitalopram & Prolongation of the QT interval & Fair & Delayed & $2(1.6)$ \\
\hline $\begin{array}{l}\text { Prochlorperazine+ } \\
\text { Escitalopram }\end{array}$ & Prolongation of the QT interval & Fair & Delayed & $2(1.6)$ \\
\hline Propoxyphene+Duloxetine & $\begin{array}{l}\text { Additive CNS- and/or respiratory-depressant } \\
\text { effects }\end{array}$ & Fair & Rapid & $2(1.6)$ \\
\hline Ciprofloxacin+Duloxetine & $\begin{array}{l}\text { Increased duloxetine concentration and toxicity } \\
\text { (mental status changes, autonomic dysfunction, } \\
\text { neuromuscular abnormalities and gastrointestinal } \\
\text { symptoms) }\end{array}$ & Poor & Delayed & $2(1.6)$ \\
\hline Lorazepam+Olanzapine & $\begin{array}{l}\text { Additive CNS and/or cardiorespiratory, depressant } \\
\text { effects }\end{array}$ & Poor & Rapid & $2(1.6)$ \\
\hline Warfarin+Aspirin & Increased risk of bleeding & Good & Delayed & $2(1.6)$ \\
\hline $\begin{array}{l}\text { Chlorpheniramine+ } \\
\text { Propoxyphene }\end{array}$ & $\begin{array}{l}\text { Additive CNS and/or respiratory-depressant } \\
\text { effects }\end{array}$ & Fair & Rapid & $2(1.6)$ \\
\hline $\begin{array}{l}\text { Aluminum } \\
\text { hydroxide+Sodium citrate }\end{array}$ & $\begin{array}{l}\text { Increased serum aluminum concentrations and } \\
\text { toxicity (hyperaluminemia and encephalopathy) }\end{array}$ & Poor & Rapid & $1(0.8)$ \\
\hline Naproxen+Methotrexate & Increased methotrexate concentrations and toxicity & Good & Delayed & $1(0.8)$ \\
\hline Propoxyphene+Pregabalin & $\begin{array}{l}\text { Additive CNS and/or respiratory-depressant } \\
\text { effects }\end{array}$ & Fair & Rapid & $1(0.8)$ \\
\hline Propoxyphene+Flavoxate & $\begin{array}{l}\text { Additive CNS and/or respiratory-depressant } \\
\text { effects }\end{array}$ & Fair & Rapid & $1(0.8)$ \\
\hline Albuterol+Carvedilol & $\begin{array}{l}\text { Antagonize the effects of beta- } 2 \text { adrenergic } \\
\text { bronchodilators and precipitate acute, life- } \\
\text { threatening bronchospasm }\end{array}$ & Good & Rapid & $1(0.8)$ \\
\hline $\begin{array}{l}\text { Prochlorperazine+Topirama } \\
\text { te }\end{array}$ & Oligohidrosis, hyperthermia & Poor & Delayed & $1(0.8)$ \\
\hline Topiramate+Quetiapine & Oligohidrosis, hyperthermia & Poor & Delayed & $1(0.8)$ \\
\hline Verapamil+Tizanidine & $\begin{array}{l}\text { Increased plasma concentrations and adverse } \\
\text { effects of tizanidine }\end{array}$ & Fair & Delayed & $1(0.8)$ \\
\hline $\begin{array}{l}\text { Carbamazepine+Prop- } \\
\text { oxyphene }\end{array}$ & Increased plasma concentrations of carbamazepine & Fair & Rapid & $1(0.8)$ \\
\hline Carbamazepine+Linezolid & Serotonin Syndrome & Good & Rapid & $1(0.8)$ \\
\hline Allopurinol+Lisinopril & $\begin{array}{l}\text { Hypersensitivity reactions } \\
\text { (Stevens-Johnson syndrome, } \\
\text { skin eruptions, anaphylactic } \\
\text { coronary spasm) }\end{array}$ & Poor & Delayed & $1(0.8)$ \\
\hline Clopidogrel+Pioglitazone & Increased plasma concentrations of pioglitazone & Poor & Rapid & $1(0.8)$ \\
\hline Quetiapine+Escitalopram & Prolongation of the QT interval & Fair & Delayed & $1(0.8)$ \\
\hline Calcitriol+Cholecalciferol & $\begin{array}{l}\text { Vitamin D toxicity (hypercalcemia, hypercalciuria, } \\
\text { and hyperphosphatemia) }\end{array}$ & Poor & Rapid & $1(0.8)$ \\
\hline
\end{tabular}


The implications drawn from our study recommend appropriate follow up procedure to be adopted to avoid any possible adverse effect as a result of administration of multiple drugs simultaneously by patients.

Surveillance and observational procedures used for scrutinizing each and every patient's DDIs will be irksome, tedious, and sometimes futile. Also it produces more burden upon healthcare practitioners. Furthermore, DDIs of minor intensities are of no clinical value.Every medical aid provider cannot differentiate DDIs from ADRs, and therefore, cannot take appropriate remedy or restorative therapy accordingly.

If clinicians are being made well aware about the DDIs encountered, the occurrence of undesirable outcomes can be minimized. Therefore, there must be clinical guidelines properly formulated and implemented in healthcare settings especially important for the visiting patients' health safety.

The most frequently interactions of drugs noticed in our study are: Theophylline plus albuterol, theophylline plus salbutamol, theophylline plus omeprazole, aspirin plus omeprazole, aspirin plus losartan, furosemide plus aspirin, omeprazole plus atorvastatin, aspirin plus nitroglycerin, albuterol plus salmeterol, and albuterol plus fluticasone. Our findings are different than previous studies performed due to different interactions screening process, and different drug prescriptions.

There were no patients admitted in the hospital as a result of major severe drug-drug interactions in two months period. The possible reason behind may be the availability of various healthcare settings in the close vicinities, lack of patient awareness, or non provision of patients' follow up plan.

\section{Limitations of the study}

Only OPD patients were being analyzed in the study. The results might be different if other specialities were being considered. Thus multi-speciality studies are recommended. Also only one drug interaction screening program (Micromedex Drug-Reax $\left.{ }^{\circledR}\right)$ is used to analyze DDIs. However, other scores can also be utilized and there exists differences among different programs.

\section{CONCLUSION}

The predominance of DDIs in our findings shows a very huge percentage of patients. This may be due to the overburdening of patients over the healthcare practitioners as well as hospital's limited facilities. Lack of appropriate patients' follow up monitoring system. Scarcity of DDIs detection system also adds up to adversity of situation.

\section{Recommendations}

Proper training and utilization of hospital pharmacists is needed to combat the potential ADRs and DDIs occurrence in patients. Along with the healthcare medical practitioners, pharmacists, para-medical staff and nurses should take responsibility to counsel and facilitate the patients. Patients must be counselled regarding ADRs and DDIs. Latest DDI detection system must be installed.

\section{Funding: No funding sources \\ Conflict of interest: None declared \\ Ethical approval: Not required}

\section{REFERENCES}

1. Pirmohamed M, James S, Meakin S, Green C, Scott $\mathrm{AK}$, Walley $\mathrm{TJ}$, et al. Adverse drug reactions as cause of admission to hospital: prospective analysis of 18820 patients. BMJ. 2004;329:15-9.

2. Juurlink DN, Mamdani M, Kopp A, Laupacis A, Redelmeier DA. Drug-drug interactions among elderly patients hospitalized for drug toxicity. JAMA. 2003;289:1652-58.

3. Lazarou J, Pomeranz BH, Corey PN. Incidence of adverse drug reactions in hospitalized patients: a meta-analysis of prospective studies. JAMA. 1998;279:1200-5.

4. Tulner LR, Frankfort SV, Gijsen GJ, Van-Campen JP, Koks CH, Beijnen JH. Drug-drug interactions in a geriatric outpatient cohort. Drug \& Aging. 2008; 25:343-55.

5. Magro L, Moretti U, Leone R. Epidemiology and characteristics of adverse drug reactions caused by drug-drug interactions. Expert Opin Drug Saf. 2012;11:83-94.

6. Pedros C, Quintana B, Rebolledo M, Porta N, Vallano A, Arnau JM. Prevalence, risk factors and main features of adverse drug reactions leading to hospital admission. Eur J Clin Pharmacol. 2014; 70:361-7.

7. Ismail M, Iqbal Z, Khattak MB, Khan MI, Arsalan $\mathrm{H}$, Javaid A, et al. Potential drug-drug interactions in internal medicine wards in hospital setting in Pakistan. Int J Clin Pharm. 2013;35:455-62.

8. Carvalho RE, Reis AM, Faria LM, Zago KS, Cassiani SH. Prevalence of drug interactions in intensive care units in Brazil. Acta paul enferm. 2013;26:150-7.

9. Ismail M, Iqbal Z, Khan MI, Javaid A, Arsalan H, Farhadullah H, et al. Frequency, levels and predictors of potential drug-drug interactions in a pediatrics ward of a teaching hospital in Pakistan. Trop J Pharm Res. 2013;12:401-6.

10. Rafi MS, Naqvi SB, Khan MU, Fayyaz M, Ashraf N, Khan MA, et al. Evaluation of potential drug-drug interactions with antidepressants in two tertiary care hospitals. J Clin Diagn Res. 2015;9:FC05-8.

11. Vandael E, Marynissen T, Reyntens J, Spriet I, Vandenberghe J, Willems R, et al. Frequency of use 
of QT-interval prolonging drugs in psychiatry in Belgium. Int J Clin Pharm. 2014;36:757-65.

12. Van-Leeuwen RW, Brundel DH, Neef C, VanGelder T, Mathijssen RH, Burger DM, et al. Prevalence of potential drug-drug interactions in cancer patients treated with oral anticancer drugs. $\mathrm{Br}$ J Cancer. 2013;108:1071-8.

13. Chelkeba L, Alemseged F, Bedada W. Assessment of potential drug-drug interactions among outpatients receiving cardiovascular medications at Jimma University specialized hospital, south West Ethiopia. Int J Basic Clin Pharmacol. 2013;2:144-52.

14. Feinstein J, Dai D, Zhong W, Freedman J, Feudtner C. Potential drug-drug interactions in infant, child, and adolescent patients in Children's hospitals. Pediatrics. 2015;135:e99-108.

15. Patel PS, Rana DA, Suthar JV, Malhotra SD, Patel VJ. A study of potential adverse drug-drug interactions among prescribed drugs in medicine outpatient department of a tertiary care teaching hospital. J Basic Clin Pharm. 2014;5:44-8.

16. Chavda NB, Solanky PP, Baria H, Naik R, Bharti K. Study of potential drug-drug interaction between prescribed drugs in patients attending outpatient department of medicine at tertiary-care hospital in South Gujarat region. Natl J Physiol Pharm Pharmacol. 2015;5:236-42.

17. Aparasu R, Baer R, Aparasu A. Clinically important potential drug-drug interactions in outpatient settings. Research in Social and Administrative Pharmacy. 2007;3(4):426-37.
18. Janchawee B, Wongpoowarak W, Owatranporn T, Chongsuvivatwong V. Pharmacoepidemiologic study of potential drug interactions in outpatients of a university hospital in Thailand. J Clin Pharm Ther. 2005;30:13-20.

19. Saeed A, Ibrahim H. Reasons for the problems faced by patients in government hospitals: results of a survey in a government hospital in Karachi, Pakistan. J Pak Med Assoc. 2005;55:45-7.

20. Henriksen K, Battles JB, Keyes MA, Grady ML. Advances in patient safety: new directions and alternative approaches. Agency for Healthcare Research and Quality. Available at: https://www.academia.edu/9612902/Using_Patient_ Complaints_to_Promote_Patient_Safety_Agency_for _Healthcare_Research_and_Quality_Advances_in_P atient_Safety_New_Directions_and_Alternative_Ap proaches_Volume_2_2008. Accessed on 20 June 2020.

21. Micromedex Database, Truven health analytics, Greenwood Village, Colorado, USA. Available at: https://www.micromedexsolutions.com/micromedex 2/librarian. Accessed 24 June 2019.

22. Jazbar J, Locatelli I, Horvat N, Kos M. Clinically relevant potential drug-drug interactions among outpatients: A nationwide database study. Res Social Adm Pharm. 2018;14(6):572-80.

Cite this article as: Butt HA, Khan A, Suleman N. Occurrence of possible drug related interactions in medical patients in out-patient departments of Pakistan. Int J Basic Clin Pharmacol 2020;9:1503-8. 